\title{
Popularyzacja idei nowego wychowania na łamach czasopisma „Wychowanie Przedszkolne"
}

\begin{abstract}
Abstrakt
Na przełomie XIX i XX w., ogromny rozgłos w całej Europie zdobyły idee „nowego wychowania”. W upowszechnianie nowych koncepcji pedagogicznych włączyły się polskie czasopisma, wśród nich „Wychowanie Przedszkolne”. W artykule przedstawiono wnioski z analizy treści artykułów, zamieszczanych na łamach pisma w całym okresie jego ukazywania się (1925-1939), dotyczących zagadnień „nowego wychowania" w odniesieniu do pracy z dziećmi w wieku przedszkolnym.
\end{abstract}

Słowa kluczowe: historia wychowania, wychowanie w przedszkolu, nowe wychowanie, czasopiśmiennictwo pedagogiczne.

\section{Popularisation of the Idea of New Education in the Magazine "Wychowanie Przedszkolne"}

\begin{abstract}
At the turn of the $19^{\text {th }}$ and $20^{\text {th }}$ centuries, the ideas of "new education" gained popularity all over Europe. Polish magazines joined the popularization of new concepts of pedagogical work, among them "Wychowanie Przedszkolne" (Preschool Education). The article presents the conclusions drawn from the analysis of the content of the magazine during the whole period (1925-1939) when it was published.
\end{abstract}

Keywords: history of education, kindergarten education, new upbringing, pedagogical periodicals.

\footnotetext{
* Uniwersytet Rzeszowski.

Artykuł otrzymano: 16.01.2020; akceptacja: 20.04.2020.
} 


\section{Wprowadzenie}

Na przełomie XIX i XX w. w pedagogice nastąpił przełom, którego celem było obalenie dotychczasowej, tradycyjnej szkoły, a równocześnie stworzenie nowej koncepcji wychowania. Na zachwianie klasycznej teorii i praktyki pedagogicznej miały wpływ różne czynniki, wśród nich m.in.: szybki rozwój ekonomiczny i społeczny, wzrost kontaktów międzynarodowych, rozwój badań w zakresie nauk biologicznych, psychologicznych i pedagogicznych. Coraz powszechniejsze stało się przekonanie, że człowiek nie jest istotą pojedynczą i odosobnioną, ale wyrasta zawsze z jakiegoś podłoża, rozwija się na tle pewnego środowiska przyrodniczego, społecznego i kulturalnego i wraz z tym środowiskiem stanowi sensowną całość (Chmaj 1962: 17). Wraz ze wzrostem wiedzy biologicznej i psychologicznej o człowieku rozszerzyła się wiedza o dziecku, jego fazach rozwojowych, potrzebach i zainteresowaniach. Dziecko zaczęto pojmować jako wartość samą w sobie, której przysługuje prawo do zaspokajania podstawowych potrzeb, zapewnienia odpowiednich warunków rozwoju i ochrony zdrowia. Nowe spojrzenie na dziecko spowodowało ogromne zmiany w podejściu do kwestii wychowawczych i dało początek rozwoju tzw. „nowego wychowania” - ruchu pedagogicznego zmierzającego do odnowy szkoły i radykalnej zmiany w wychowaniu (Drynda 2000: 29). John Dewey, jeden z najwybitniejszych pedagogów amerykańskich, propagator „nowego wychowania”, w 1899 r. pisał:

Otóż zachodząca obecnie zmiana w systemie nauczania polegać będzie na przesunięciu środka ciężkości. Jest to zmiana, przewrót podobny do tego jakiego dokonał Kopernik, gdy przesunął środek astronomiczny z Ziemi na Słońce. W tym wypadku dziecko staje się słońcem, wokół którego krążyć mają poczynania wychowawcze, tym ośrodkiem, wokół którego mają się organizować (Dewey 1967: 95).

Szkoła tradycyjna, której podstawę teoretyczną stanowił herbartyzm, zaczęła być ostro krytykowana. Dostrzegano jej małą skuteczność dydaktyczno-wychowawczą, krytykowano ją za autorytaryzm, krępowanie swobody dziecka, dogmatyzm, intelektualizm, statyczność oraz niedostosowanie do nowej sytuacji społecznej. Protest i krytykę prowadzono w myśl idei szacunku i wolności indywidualizmu dziecka (Sośnicki 1967: 46). Równocześnie zaczęto szukać nowych form, metod i programu wychowawczego w celu należytego dostosowania do potrzeb rozwojowych i zainteresowań dziecka. Apelowano o stworzenie jak najlepszych warunków umożliwiających wszechstronny, a równocześnie indywidualny rozwój każdego dziecka. W związku z tym domagano się:

- dokonania radykalnej zmiany w wychowaniu poprzez idee poznania dziecka i zapewnienia mu swobodnego rozwoju psychicznego i fizycznego zgodnego z jego indywidualnymi cechami, potrzebami i zamiłowaniami, 
- zreformowania kształcenia i wychowania, uwzględniającego przygotowanie do czynnego udziału młodzieży w życiu społeczeństwa, narodu oraz rozwijania silnego charakteru i tężyzny fizycznej,

- ograniczenia ilości niektórych teoretycznych treści nauczania na rzecz zajęć praktycznych oraz przedmiotów przyrodniczo-matematycznych, artystycznych i języków nowożytnych,

- zapewnienia warunków do spontanicznej aktywności uczniów, rozwijania ich zainteresowań poznawczych, samodzielności w myśleniu i działaniu praktycznym,

- indywidualizacji procesu kształcenia, z uwzględnieniem potrzeb, zdolności i tempa pracy uczniów poprzez zastąpienie metod podających poszukującymi (Drynda 2000: 36).

Nowe idee stanowiły przedmiot wielu, toczących się na przełomie XIX i XX w., dyskusji pedagogicznych. Postulaty „nowego wychowania” głoszono podczas międzynarodowych i krajowych kongresów, zjazdów czy konferencji (Kabzińska 2001: 188-208; Jamrożek 2001: 121-137). Popularne stały się hasła, w których podkreślano, iż:

przy zmierzchu starego świata i zorzy nowo-wschodzącego, kiedy stare metody rządzenia, stare praktyki ekonomiczne okazały się bezsilne dla przebudowy społeczeństwa, wychowanie pokolenia zdolnego zamieszkać i żyć w nowym domu jest problemem pierwszorzędnym (Międzynarodowy... 1932: 171).

W Polsce największe upowszechnienie „nowego wychowania” nastąpiło po odzyskaniu niepodległości (Sobczak 1998: 32). Po roku 1918 nastąpił też wzmożony rozwój czasopiśmiennictwa, które stało się istotną platformą wymiany różnych poglądów, w tym dotyczących kwestii wychowawczych (Kabzińska, Kabziński 2010: 215). Liczne periodyki pedagogiczne popularyzowały i interpretowały dorobek polskiej i światowej myśli pedagogicznej oraz włączyły się w dyskusje nad koncepcją polskiej oświaty. Czasopisma na swoich łamach prezentowały nowe idee oraz formy i metody pracy dydaktyczno-wychowawczej oparte o nowatorskie koncepcje. Wśród polskiej prasy pedagogicznej okresu międzywojennego istotne miejsce zajmowało czasopismo „Wychowanie Przedszkolne”, które włączyło się w popularyzację „nowego wychowania”.

\section{„Wychowanie Przedszkolne” jako nowatorskie czasopismo pedagogiczne}

„Wychowanie Przedszkolne” z podtytułem: Czasopismo poświęcone sprawom wychowania dzieci $w$ wieku przedszkolnym, adresowane do wychowawczyń przedszkolnych, wydawane było w Warszawie jako organ Towarzystwa Wychowania 
Przedszkolnego. Periodyk ten był najdłużej wydawanym pismem, dotyczącym wychowania przedszkolnego w okresie II Rzeczpospolitej. Ukazywał się od stycznia 1925, bez przerwy aż do wybuchu II wojny światowej. Ostatni numer pisma ukazał się w sierpniu 1939 r. Początkowo czasopismo wydawane było jako miesięcznik, a od 1931 r. jako dwumiesięcznik. Założone i przez cały okres istnienia redagowane było przez Marię Weryho-Radziwiłłowiczową - wybitną pedagog, organizatorkę i działaczkę społeczną, publicystkę, autorkę licznych publikacji metodycznych, prac teoretycznych i powiastek dla dzieci (Moliere 1982: 458; Raczek 2001: 81-87). Redakcja czasopisma mieściła się w Warszawie, przy al. 3-go Maja, w mieszkaniu założycielki. Z czasopismem współpracowali wybitni ludzie nauki, psycholodzy, pedagodzy, lekarze, którzy przyczynili się do jego wysokiego poziomu. Do grona współpracowników należeli: Maria Uklejska, Zofia Żukiewiczowa, Lucyna Molendzińska-Wernerowa, Iza Moszczeńska, Natalia Cicimirska, Wanda Krahelska-Mackiewicz, Wanda Daszewska, Barbara Żulińska, Maria Młodowska, Nina Bobieńska, Maria Gerson-Dąbrowska, Zofia Bogdanowiczowa, Maria Librachtowa, Felicja Kiełbikowa, Zofia Biernacka, Maria Kaczkowska, Anna Jakimiakowa, Janina Porazińska, Ewa Szelburg-Zarębina, Stefania Tucholska, Rafał Radziwiłłowicz, Janusz Korczak, Henryk Trenkner, Stefan Szuman, Władysław Sterling (Sosnowska 2016: 6).

Redakcja czasopisma, od początku jego istnienia, dostrzegała potrzebę zainteresowania szerszego grona problemem wychowania przedszkolnego, nazywając je „kopciuszkiem pedagogicznym”. Położyła główny akcent na rozwój i właściwe przygotowanie do zawodu wychowawczyń w myśl nowej wiedzy pedagogicznej. Już w pierwszym numerze, w założeniach redakcyjnych czytamy:

Społeczeństwo otacza szkołę należytą opieką - przedszkole natomiast jest w znacznie mniejszym stopniu przedmiotem troski ogólnej, jakkolwiek jest oczywiste znaczenie, jakie przedstawia ta dziedzina wychowania, jako podstawa do pracy szkolnej. Niedość jest posiadać przedszkola i seminaria, trzeba myśleć o wychowawczyniach, o dalszym ich rozwoju; trzeba umożliwić im zdobywanie nowego materiału myślowego, dostarczyć im wskazówek potrzebnych, uprzystępnić dostęp do nowych zdobyczy pedagogicznych w zakresie ich zawodu (...) Nie mamy zamiaru krępować inicjatywy wychowawczyń przez narzucanie im gotowych schematów lub wzorów, przeciwnie - pismo będzie dążyć do tego by młodym pracownikom dostarczyć materiału do własnej, dalszej, samodzielnej przeróbki myślowej, do dania im możności zapoznania innych $\mathrm{z}$ wynikami ich w własnej obserwacji (Weryho 1925: 1).

W związku z tym, zgodnie z założeniami redakcyjnymi, w piśmie publikowano: artykuły naukowe i metodologiczne z zakresu pedagogiki, doniesienia o stanie wychowania przedszkolnego w kraju i zagranicą, praktyczne wskazówki dla wychowawczyń do prowadzenia zajęć przedszkolnych, w tym materiały dydaktyczne i przykładowe scenariusze zajęć, sprawozdania $\mathrm{z}$ nowatorskich przedsięwzięć 
dotyczących wychowania przedszkolnego oraz recenzje nowości wydawniczych (książek pedagogicznych i literatury dziecięcej).

Analiza treści zamieszczanych artykułów pozwala na sformułowanie tezy, iż „Wychowanie Przedszkolne” bardzo aktywnie upowszechniało na swych łamach idee „nowego wychowania”. Prześledzenie treści artykułów z tego zakresu, w całym okresie wydawania czasopisma, umożliwia wyodrębnienie kilku obszarów, wokół których koncentrowała się owa tematyka. Popularyzacja „nowego wychowania” realizowana była w czasopiśmie poprzez:

- przedstawianie nowatorskich koncepcji wychowania i ich twórców;

- prezentacje zagranicznych placówek przedszkolnych, pracujących w oparciu o nowe idee;

- omawianie metod i form wspierania poszczególnych sfer rozwoju dzieci według koncepcji „nowego wychowania”.

\section{Nowatorskie koncepcje wychowania przedszkolnego}

Na przestrzeni całego okresu ukazywania się czasopisma znajdujemy teksty prezentujące idee „nowego wychowania”. Wśród nich jest sporo artykułów popularyzujących metody Montessori, Claparède, Froebla, Deweya, Decroly'ego, z akcentowaniem ich pozytywnych rezultatów dla rozwoju dzieci. Znajdują się też konkretne wskazówki metodyczne dla wychowawczyń, mające zachęcić je do stosowania omówionych metod oraz przekonać do dokształcania i dokładnego poznania nowatorskich sposobów pracy dydaktyczno-wychowawczej.

Przykładowo w artykule opublikowanym w 1925 r. znajdujemy szczegółową prezentację metody Montessori. Autorka wskazuje przede wszystkim na walory nowoczesnego wyposażenia budynku, dającego dzieciom możliwość swobodnego poznawania świata. Zwraca uwagę na konieczność zastosowania lekkich, jasnych mebelków, dostosowanych do wzrostu dzieci, utrzymywania porządku, „który przemawia do dziecka wyraźniej i silniej niż napomnienia dorosłych" (Grunwald 1925: 15). Podkreśla też społeczny aspekt samodzielnych działań dziecka, które „zamiata, czyści klamki, myje naczynia, obciera mebelki z kurzu, dba o kwiaty, zwierzęta, pracuje w ogrodzie” (tamże: 16), ale przy tym powinno „łączyć się z towarzyszami swoimi dla wykonania jakiejś pracy, musi wytworzyć jakiś podział pracy, a na tym gruncie powstaje i wyrasta życie społeczne" (tamże: 17). Ćwiczeniu samodzielności i koncentracji, tak ważnych cech w rozwoju małego dziecka, mają pomagać przygotowane odpowiednio pomoce dydaktyczne. Montessori nazywała je „materiałem rozwojowym” podzielonym na kilka działów: do ćwiczeń z życia codziennego, kształcenia zmysłów, edukacji matematycznej, wychowania religijnego i dla kultury życia. Do metody montessoriańskiej powracano niejednokrotnie na łamach pisma, często dokonując porównań z metodą Froebla czy Decroly’ego. 
Czasami pojawia się też krytyka pewnych elementów metody. Przykładowo w artykule Pomoce wychowawcze MAR BIC z roku 1933 czytamy:

pomoce wychowawcze Montessorii mogą być użyteczne dla dzieci małych 2-4 lat, odpowiadają ich rozwojowi i wymaganiom, ale są niewystarczające dla tych, które przeszły ten wiek. Dziecko do lat 4 zadowala się materiałem który daje pole do zabaw bardzo prostych: ustawi wieżę, schodki, dobierze odcienie barw, posegreguje walce różnej wielkości itp., ale co ponadto może wykonać dziecko starsze z owym materiałem który nie nadaje się do zrealizowania własnych pomysłów? (Biciulescu 1933: 31).

O metodzie Montessori znajdujemy też obszerny artykuł w 1928 r. autorstwa Z. Bogdanowiczowej. Przedstawia ona założenia i zasady pracy dydaktyczno-wychowawczej w przedszkolu „Casa dei Bambini”. Autorka podkreśla, że Montessori przy organizowaniu placówek kieruje się zawsze wartą naśladowania zasadą, w której stwierdza, iż: „najwyższym szczęściem człowieka jest poczucie i zdanie sobie sprawy z własnej siły wobec siebie i otoczenia" (Bogdanowiczowa 1928: 122).

Na uwagę zasługuje również artykuł pt. Dom Dzieci przy Instytucie J.J. Rousseau, opracowany przez jego kierowniczki, gdzie zaprezentowano stosowane metody pracy wychowawczej. Był to zakład przeznaczony dla dzieci w wieku 3-9 lat, a zajęcia odbywały się w specjalnie wyodrębnionych pomieszczeniach. Był tam pokój budowniczych, modelowania, mowy, rachunków, spostrzegawczości i wyobraźni. Wszystkie pomieszczenia były odpowiednio wyposażone w meble i pomoce dostosowane do wzrostu i potrzeb dzieci. Pomoce dydaktyczne stanowiły kulki, laski, kartki z liczbami pomagające w rozumieniu pojęć matematycznych. Dzieci podzielone były na grupy nie według wieku, a według poziomu ich rozwoju, miały też swobodę wyboru zajęć. Podstawą uczenia się było ćwiczenie zmysłów, spostrzegania i kształtowania pojęć (Audemars, Lafendel 1938: 6-16, 39-44).

Na łamach pisma, w myśl „nowego wychowania”, wielokrotnie postulowano prowadzenie ścisłej współpracy z rodzicami (Witkowski 1938: 1-2; Wierzbińska 1938: 304). W jednym z artykułów, autorka wymienia i poleca stosować różne formy współpracy z rodzicami, wśród nich np.:

- dyżury matek w urządzaniu wycieczek, uroczystości i wspólnych zabaw,

- zebrania dla rodziców i omawianie kwestii opiekuńczo-wychowawczych,

- pogadanki pedagogiczne dla rodziców,

- indywidualne spotkania z rodzicami, w stałych porach 1-2 razy w tygodniu, w celu wymiany spostrzeżeń z prowadzonych obserwacji dziecka (Uziembło 1938: 168-169).

Wszystkie te formy współpracy autorka uznaje za konieczne we wspólnym postępowaniu wychowawczym, co najlepiej służy rozwojowi dziecka, a równocześnie pozwala na zachowanie jego indywidualności. W tekście czytamy: 
Współpraca wychowawczyni z domem dziecka jest dziś jednym z podstawowych zadań przedszkola. Opierając się na najnowszych zdobyczach pedagogiki i psychologii jest przedszkole terenem, z którego rodzice mogą czerpać wzory dla siebie. Dom zaś w rozumieniu zadań i celów przedszkola oddziaływa na dziecko nie z egoistycznego punktu widzenia, ale ze zrozumieniem, że dziecko jako członek społeczeństwa do niego przede wszystkim należy (Uziembło 1938: 167).

Popularyzacji nowych idei dokonywano w piśmie również poprzez publikowanie sprawozdań z międzynarodowych kongresów, zjazdów i konferencji, poruszających kwestie pedagogiczne. Przykładowo, w jednym z numerów zamieszczono obszerne Sprawozdanie z Kongresu Nowego Wychowania w Nicei, który odbył się w dniach 29.07.-12.08.1932 r. (Międzynarodowy... 1932: 170-173). W tekście przytoczone są m.in. cele wychowania zaprezentowane podczas kongresu przez Ligę Nowego Wychowania. Wynika z nich, że:

Wychowanie winno dać dziecku możność zrozumienia wszystkich przejawów życia społecznego i ekonomicznego naszej epoki. Winno ono odpowiadać potrzebom intelektualnym i uczuciowym dzieci o rożnych temperamentach, umożliwiając im wyrażanie się w formie odpowiadającej ich właściwościom. Winno dopomóc dziecku w przystosowaniu się do życia społecznego, zastępując karność opartą na przymusie i strachu, przez rozwój inicjatywy i poczucie odpowiedzialności. Winno sprzyjać współpracy nauczycieli i uczniów z uwzględnieniem różnic charakteru i niezależności umysłu. Winno doprowadzić dziecko do tego, by umiejąc cenić dziedzictwo własnego narodu, przyjmowało radośnie od obcego narodu wszystko to, co może przyczynić się do powszechnej kultury ludzkości (tamże: 171).

W czasopiśmie znajdujemy też sprawozdanie z Międzynarodowego Kongresu w Locarno z 1925 r. Omówiono w nim przede wszystkim wystawę pedagogiczną towarzyszącą Kongresowi, na której zaprezentowano rożne eksponaty z przedszkoli z Warszawy, m.in. rysunki, wycinanki i prace dziecięce, pomoce dydaktyczne, fotografie ilustrujące organizację pracy w przedszkolach, zbiór książek obrazkowych dla dzieci polskich wydawnictw itp. (Żukiewiczowa 1927: 14).

Redakcja pisma z dużym szacunkiem odnosiła się również do wszelkich wydarzeń związanych z twórcami koncepcji „nowego wychowania”. Na łamach „Wychowania Przedszkolnego" zamieszczano życiorysy wybitnych pedagogów, przypominano o ich osiągnięciach przy okazji różnych rocznic czy wydarzeń. I tak chociażby w 1932 r. znajdujemy obszerny artykuł o życiu i działalności F. Froebla z okazji 150 rocznicy jego urodzin (Bobkowska 1932: 64-69). W innym numerze pisma z kolei jest nekrolog 0. Decroly’ego i podkreślone jego zasługi jako twórcy „ośrodków zainteresowań" (Nekrolog... 1932: 161). 
Przedstawiając samo znaczenie i cel wychowania przedszkolnego, niejednokrotnie odwoływano się do poglądów przedstawicieli nowego nurtu. W jednym z tekstów podkreślono, że zgodnie z myślą O. Decroly'ego rola przedszkola:

polega na okazaniu pomocy rodzinie w wychowaniu dziecka i przygotowaniu do szkoły. Przez szereg gier wychowawczych, stopniowych co do trudności, doprowadza się dziecko do tego, że dobrze widzi i słyszy, interesuje się wszystkim co je otacza, nabywa trafnych wiadomości. Uczy się obserwować, wyrażać myśli rozwija się zdolność inwencji i twórczość. Zaszczepia się potrzebę porządku i czystości, ochotę do pracy i miłość dobra, ten potrójny fundament wychowania estetycznego i moralnego $\mathrm{COd}$ redakcji 1932: 1).

\section{Realizacja idei „nowego wychowania” w placówkach przedszkolnych}

„Wychowanie Przedszkolne” poświęcało na swoich łamach sporo miejsca na prezentację różnych przedszkoli zagranicznych, pracujących w oparciu o pedagogikę „nowego wychowania”. Już w 1925 r. zamieszczono artykuł Anny Jakimiakowej Przedszkola Paryskie, w których autorka prezentuje te zachodnie placówki (Jakimiakowa 1925: 1-11). Zachwala przede wszystkim nowoczesne wyposażenie, dostosowane do potrzeb rozwojowych dzieci. Pisze o jasnych, słonecznych, przestronnych salach do zajęć, osobnej jadalni, wyposażonej w bieżącą wodę łazience, ogrodzie przy budynku. Dodatkowo opisuje zajęcia dydaktyczne prowadzone metodą „ośrodków zainteresowań” 0. Decroly’ego i M. Montessori.

Z kolei w 1926 r., znajdujemy artykuł pt. Przedszkola $w$ Belgii, z którego dowiadujemy się o panującej $\mathrm{w}$ tamtejszych przedszkolach serdecznej, rodzinnej atmosferze, sprzyjającej stymulowaniu rozwoju dzieci. Placówki omówione w artykule, prowadzone są w oparciu o koncepcję pracy F. Froebla, przypominają idealny dom rodzinny, w którym wychowawczyni, jak dobra matka, opiekuje się gromadką (niewielką liczbą dzieci), uwzględniając indywidualność i potrzeby każdego z nich. W placówce ławki szkolne zastąpiono stolikami i krzesłami, które umożliwiają swobodne ruchy. Zajęcia w dużej mierze odbywają się na świeżym powietrzu, na podwórku obok budynku. Dzieci samodzielnie, z dyskretną pomocą wychowawczyń opiekują się roślinkami i zwierzętami, co uczy je odpowiedzialności i wrażliwości (Moreau 1926: 11-12).

W tym samym numerze pisma ukazał się również interesujący artykuł o przedszkolach austriackich (B.G. 1926: 8-9). Podkreślono w nim, że w placówkach tych dużą wagę przywiązuje się do osoby wychowawczyni, która je prowadzi i „szuka rzeczy nowych, czyta, obserwuje dzieci, daje swoje oryginalne pomysły gier, zajęć, pomocy do ćwiczeń (tamże: 9). W związku z tym wychowawczyni powinna być dobrze przygotowana zawodowo. Jak czytamy dalej: „trzy seminaria 
ochroniarskie istniejące w Wiedniu umożliwiły (...) dokładne zaznajomienie się z psychiką dziecka i zgłębienie się w ideę przedszkoli, a same wychowawczynie są świadome powagi obranego przez siebie zawodu" (tamże: 9).

O przedszkolach wiedeńskich, jako wzorcowych, czytamy też w artykule I. Schreibera w 1935 r. Autor przedstawia w nim zasady działalności Rady Szkolnej miasta Wiednia w zakresie dydaktycznej opieki nad placówkami przedszkolnymi. Omawia m.in. funkcjonowanie przedszkoli dla dzieci „trudnych do prowadzenia”, czyli niesłyszących i niedorozwiniętych umysłowo, w których wyposażenie oraz praca dydaktyczno-wychowawcza oparta została o zasady pedagogiki M. Montessori i F. Froebla (Schreiber 1935: 34-39). W przedszkolach tych przyjęto za podstawę freblowskie wskazania: „aby rozwinąć w sposób planowy tkwiące w dziecku popędy ruchu i naturalną wolę działania i wzbudzić przez obcowanie z rówieśnikami poczucie społeczne" (tamże: 35), które przyniosły pozytywne rezultaty i rozwój każdego dziecka.

Z kolei w jednym z numerów pisma z 1927 r. jest artykuł Wychowanie przedszkolne w Szwajcarii, w którym czytamy:

wychowanie przedszkolne jest dobrem nieocenionym. Wszak zadaniem jego jest ulżyć rodzicom, ułatwić pracę nauczycielom w szkołach powszechnych, zająć dzieci, kształcić ich zmysły bez zbytniego wysiłku, nie dopuszczać do zupełnego próżniactwa i szkodliwego przemęczenia umysłowego (F.M. 1927: 7).

Ze względu na te korzyści w Szwajcarii czyniono starania, aby w każdej, nawet malutkiej miejscowości powstała placówka wychowawcza dla małych dzieci. Autor tekstu zachęca do naśladowania takich przedsięwzięć w Polsce.

W innym artykule Z. Bogdanowiczowa przytacza zadania tzw. nowych przedszkoli w Stanach Zjednoczonych. Podkreśla, że praca w nich koncentruje się na trzech podstawowych aspektach, tj.:

- okazywaniu stałej pomocy w rozwijaniu osobowości dziecięcej, a przede wszystkim w odnajdywaniu przez dziecko właściwego miejsca w społeczności;

- stwarzaniu okoliczności sprzyjających zdobywaniu nowych wyobrażeń;

- uodpornianiu dziecka pod względem fizycznym przez stworzenie warunków zdrowotnych i wytwarzaniu przyzwyczajeń higienicznych (Bogdanowiczowa 1936: 134).

Autorka artykułu podkreśla ogromne znaczenie nauczycielek w realizacji wymienionych zadań. Stwierdza: „wychowawczyni musi łączyć cech artysty i naukowca. Umieć tworzyć, a równocześnie obserwować i wyciągać słuszne wnioski z obserwacji (Bogdanowiczowa 1936: 134). Z kolei w tekście pt. Z dziedziny wychowania przedszkolnego $w$ Ameryce opisano wyposażenie jednego z funkcjonujących tam wzorcowych przedszkoli (Podolecka 1928: 199-200). Dowiadujemy się, że placówka zajmuje 3 pomieszczenia: „dużą salę do zabaw, pokój nauczycielski i umywalnię. Prócz tego jest obszerne słoneczne podwórze. W sali stoi fortepian, 
wyplatane mebelki i stół z piaskiem. Prócz tego wielka ilość zabawek, klocków różnej wielkości, welocypedy, wózki, lalki i sprzęty dla nich (Podolecka 1928: 199). Autorka podkreśla, że takie wyposażenie, dostosowane do wieku, wzrostu i potrzeb dzieci sprzyja ich prawidłowemu rozwojowi i powinno być zapewnione w każdym przedszkolu w naszym kraju.

W czasopiśmie omawiano pracę wielu placówek przedszkolnych jeszcze z innych państw, m.in. Niemiec, Szwajcarii, Rumunii, Stanów Zjednoczonych (Kosmowska 1927: 3-5). W odniesieniu do wzorów zachodnich wielokrotnie wymieniano korzyści z jak najwcześniejszego objęcia dzieci nowoczesnym wychowaniem przedszkolnym. Przykładowo J. Wuttkowa stwierdza:

przedszkola w myśl nowego wychowania są po to, by dać dzieciom miejsce, w którym będą przebywały, nie tylko po to by były pielęgnowane i chronione, ale po to by wpływać na nie w myśl najszlachetniejszych postulatów wychowania opartych na zdobyczach współczesnej nauki, by zbudzić w dziecku drzemiące uzdolnienia i rozumnie kierować rozwojem fizycznym, moralnym i społecznym, by je poznać (Wuttkowa 1928: 128).

W związku z tak wieloma walorami nowoczesnych placówek przedszkolnych, na łamach „Wychowania Przedszkolnego” przekonywano o potrzebie zmian organizacyjnych w polskich placówkach i konieczności dostosowania ich do nowych koncepcji.

\section{Metody i formy wspierania poszczególnych sfer rozwoju dzieci w wieku przedszkolnym}

W licznych numerach pisma, na przestrzeni całego okresu jego wydawania, publikowano teksty z zakresu psychologii dziecka z uwzględnieniem wyników najnowszych badań naukowych. Zaliczyć możemy do nich artykuły dotyczące poszczególnych sfer rozwoju dzieci. Przykładowo o rozwoju umysłowym dzieci pisali wielokrotnie psycholodzy: Sterling, Szuman i in. Zachęcali oni do prowadzenia ćwiczeń rozwijających myślenie, kojarzenie, spostrzeganie. Prezentowali różne metody symulowania rozwoju poznawczego dzieciํํ. W jednym z artykułów czytamy:

wychowanie przedszkolne dążyć winno do zmniejszenia wszelkimi sposobami podświadomego poczucia małowartościowości u wychowanków. Prowadzi do tego możliwie najwcześniejsze usamodzielnianie dziecka, kształcenie zmysłów, sprawności ruchów, pożyteczna praca dziecięca, wzmaganie odwagi (Piotrowska 1931: 6).

\footnotetext{
1 Na temat poznawczego rozwoju dzieci pisali: Sterling (1930: 5), Szuman (1931: 129-134), Z.B. (1933: 155-156), Lingard (1933: 157), NN (1930: 228), R.J. (1930: 253-254).
} 
Często publikowano również teksty o rozwoju społecznym dzieci. W jednym z nich Szuman stwierdza:

metody wychowawcze muszą obrać drogę pośrednią między zbytnią surowością i zbytnim rozpieszczaniem, muszą uszanować naturalny subiektywizm uczuciowy dziecka, a równocześnie powoli uczyć je spojrzenia obiektywnego na rzeczywistość. Żywych impulsów, popędów dziecka nie wolno gwałtem stłumiać, zduszać. Psychoanaliza wykazała nam jasno niebezpieczeństwo takiego postępowania (Szuman 1932: 135).

W periodyku również bardzo często wypowiadano się na temat zajęć praktycznych, tak ważnych z punktu widzenia „nowego wychowania”. Podkreślano ich znaczenie dla rozwoju poznawczego i społecznego dzieci oraz ich usamodzielniania. Niemalże w każdym numerze znajdujemy propozycje zajęć praktycznych, ich szczegółowe scenariusze oraz np. instrukcje wykonywania różnych przedmiotów w ramach tzw. prac ręcznych. Najczęściej zamieszczano sposób wykonania zabawek, kukiełek do teatrzyku czy ozdób świątecznych ${ }^{2}$. Podkreślano przede wszystkim korzyści prac ręcznych dla rozwoju dzieci, ale także wartość samodzielnie wykonanych przedmiotów. Pisano: „odtąd wykonane samodzielnie ciężarowe samochody, autobusy, poczta, tramwaj, auto strażackie, hokej - stają się najulubieńszymi zabawkami dzieci” (Chrościńska 1936: 152).

Zgodnie z koncepcją „nowego wychowania” podkreślano często konieczność dbania o rozwój fizyczny i zdrowie dzieci w wieku przedszkolnym. Dużo artykułów z tego zakresu publikowała E. Podgórska (1936a: 9-11, 1936b: 83, 1935: 174-175, 1931: 157). W swoich tekstach wielokrotnie zachęcała do prowadzenia różnorodnych ćwiczeń gimnastycznych z dziećmi, przyczyniających się do ogólnego ich rozwoju. W jednym z artykułów stwierdziła przykładowo: „skoki należą do ćwiczeń czynności wegetatywnych, ale wpływają też na nasz układ ruchowy i wymagają dużego wysiłku nerwowego. Są to zatem ćwiczenia wszechstronne" (Podgórska 1936b: 83). W kilku numerach pisma E. Podgórska zamieściła ciekawe propozycje ćwiczeń, równocześnie stwierdzając: „wyszkolonej wychowawczyni, która sumiennie przepracowała zasady ćwiczeń ruchowych w przedszkolu, nie zabraknie materiału do zabaw ruchowych, umiejętnie wybieranych z pośród zabaw znanych i czerpanych z własnej pomysłowości (Podgórska 1935: 175).

Sporo miejsca w piśmie zajmowały publikacje dotyczące zapobiegania chorobom u dzieci i sposobów postępowania w przypadku ich wystąpienia ${ }^{3}$. W tekstach tych pisano o racjonalnym odżywianiu dzieci, zasadach zdrowego stylu życia

\footnotetext{
2 Więcej na ten temat: Gromanówna (1935: 184-185), Klecamówna (1939: 27-29), Bobieńska (1936: 1-5), NN (1927: 23-24), Pyciarzówna (1937: 25-26), Zgrychowa (1939: 152-156).

3 Więcej na ten temat: Bogdanowicz (1939: 8-10), Łuniewska (1930: 213-215), Łuniewska (1932: 6-8), Łuniewska (1936: 11-12).
} 
polegającego na hartowaniu oraz dbaniu o higienę ciała i czystość pomieszczeń. Przykładowo M. Hoffmanowa stwierdza:

higiena lokalu, w którym przebywają dzieci, winna być przestrzegana z największą skrupulatnością. Dostatecznie obszerne i słoneczne pomieszczenie, czystość, dobra wentylacja są nieodzownymi warunkami. Hartowanie dziecka przez codzienne spacery, niezależnie od pogody, niezbyt ciepłe ubieranie, czystość ciała, płukanie ust i gardła, oddzielanie zakatarzonych i kaszlących, dożywianie dzieci niedożywionych, a wreszcie uświadamianie i pouczanie matek o zachowaniu higieny dziecka w domu składałoby się na szczytne i pożyteczne zadanie opiekunki (Hoffmanowa 1937: 171).

W myśl postulatów „nowego wychowania” istotną kwestię stanowiło również wychowanie narodowe. W związku z tym na łamach pisma znajdujemy materiały dydaktyczne i gotowe scenariusze do wykorzystania podczas organizowania różnych uroczystości o charakterze patriotycznym, dotyczące obchodów różnych świąt narodowych ${ }^{4}$. Można zauważyć, że szczególnie upamiętniano rocznicę odzyskania niepodległości. W jednym z tekstów czytamy: „nie ma chyba rodziny w Polsce, gdzieby jeszcze nie żyły bezpośrednie wspomnienia legionowe walk przeżytych i tych wszystkich momentów, które prowadziły do wskrzeszenia niepodległej Polski" (H.G. 1932: 173). Zwykle w marcu publikowano wiersze i teksty do wykorzystania podczas uroczystości upamiętniających urodziny J. Piłsudskiego (W.K. 1935: 55-56). W każdym roku tradycyjnie zamieszczano ciekawe propozycje przygotowania Świąt Bożego Narodzenia czy Wielkanocy. Najczęściej publikowano teksty kolęd, scenariusze jasełek, instrukcje do wykonania ozdób choinkowych lub pisanek wielkanocnych (Kotarbińska 1932: 186-187; Erdmanówna 1937: 188).

Zgodnie z poglądami przedstawicieli „nowego wychowania” w czasopiśmie podkreślano szczególną rolę wychowawczyń w pracy z małymi dziećmi. W roku 1927 C. Bańkowska opublikowała znamienne słowa: „winniśmy pamiętać o tem, że dziecko jest centrum, jest ośrodkiem, dokoła którego wszystko, a więc wychowawczyni, program, wnętrze przedszkola i.t.p. się obraca, nie zaś odwrotnie" (Bańkowska 1927a: 3). Z kolei w innym tekście napisała:

Rola wychowawczyni w przedszkolu wobec gromadki dzieci najróżnorodniejszych typów i temperamentów, różnych co do rozwoju intelektualnego, a często i fizycznego, jest niezmiernie trudna, jeśli chodzi o t.z.w. poszanowanie indywidualności w dziecku, należącem do powierzonej jej gromadki (...) I w samej rzeczy najlepszą będzie ta metoda którą sami

\footnotetext{
${ }^{4}$ Więcej na ten temat: Kossuthówna (1937: 165), H.G (1932: 173), NN (1935: 177), Sikorska (1937: 172-174).
} 
zdobędziemy, obmyślimy i wciąż udoskonalać będziemy, czerpiąc zawsze - jak to czynili nieporównani mistrzowie wychowania: Fröbel, Montessori i od samych dzieci - tych najpierwszych, niezawodnych nauczycieli naszych! Umiejmy tylko patrzeć i słuchać! (...) Umiejętność obserwowania dzieci w każdej chwili, czy to przy zajęciu czy w zabawie, jest podług Montessori podstawą pracy naszej w ogródku dziecięcym. Dzieci same wówczas wskażą metodę właściwą, same naprowadzą na właściwe tory (Bańkowska 1927b: 4).

Popierając postulaty odpowiedniego przygotowania do pracy nauczycielek przedszkoli, w roku 1936 opublikowano Zarządzenie Ministra Wyznań i Oświecenia Publicznego dotyczące kwalifikacji zawodowych wychowawczyń przedszkoli. Wprowadzało ono obowiązek ukończenia Seminarium Nauczycielskiego, Liceum dla wychowawczyń przedszkoli lub Seminarium Ochroniarskiego, a dla czynnych zawodowo bez kwalifikacji konieczność zdawania Państwowego Egzaminu Kwalifikacyjnego (Zarzq̨dzenie... 1936: 1-2). W artykule omówiono szczegółowe zasady przystępowania do egzaminu kwalifikacyjnego, który miał obejmować: część techniczną, a w niej rysunek, śpiew, ćwiczenia fizyczne oraz część ustną obejmującą wiadomości z religii, języka polskiego, nauk o Polsce współczesnej (historia, geografia, zagadnienia gospodarcze i społeczne), psychologii, pedagogiki, metodyki nauczania przedszkolnego (Od redakcji... 1936: 35-40). Był to dowód prób dostosowywania polskiej rzeczywistości pedagogicznej do nowych standardów.

Artykuły o wspomnianej tematyce znajdujemy w całym okresie ukazywania się pisma. Objętość zamieszczanych tekstów, dotyczących idei „nowego wychowania”, była dość obszerna. Dominowały teksty dwu-, trzystronicowe, ale zdarzały się też całe cykle wykładów drukowanych w kilku numerach. Autorami publikacji byli najczęściej pedagodzy, psycholodzy i lekarze, wielu z nich uznanych na gruncie krajowym i międzynarodowym. W przeważającej mierze były to kobiety, nauczycielki zajmujące się nie tylko teorią pedagogiczną, ale również mające praktyczne doświadczenie w pracy z małymi dziećmi w przedszkolach. Autorami wielu tekstów dotyczących analizowanej tematyki byli też psycholodzy. Publikowane teksty były na wysokim poziomie merytorycznym, co czyniło czasopismo szczególnie wartościowym.

\section{Zakończenie}

Przeanalizowanie poszczególnych numerów czasopisma „Wychowanie Przedszkolne” potwierdza, że popularyzowało ono idee „nowego wychowania”. Świadczy o tym zakres zagadnieniowy publikowanych na łamach pisma tekstów. Analiza treści zamieszczanych artykułów pozwoliła równocześnie na odczytanie głównych idei „nowego wychowania”, odnoszących się do pracy z dziećmi w wieku przedszkolnym. W piśmie popularyzowano je poprzez: przedstawianie nowatorskich 
koncepcji wychowania i ich twórców; prezentowanie europejskich przedszkoli, pracujących w oparciu o nowe idee; omawianie metod i form wspierania poszczególnych sfer rozwoju dzieci według nowatorskich koncepcji. Podkreślano, że nauka i przygotowanie do życia powinny uwzględniać wrodzone zdolności i zainteresowania wychowanka, co miało się odzwierciedlać w samorzutnej aktywności, tj. w rękodzielnictwie, działalności artystycznej, intelektualnej i społecznej. Współzawodnictwo proponowano zastąpić współdziałaniem i wprowadzeniem koedukacji. Wychowanie moralne miało się odbywać poprzez wsłuchiwanie się we własną siłę wewnętrzną, stopniowe poszukiwanie krytycyzmu i wolności. Nagrody i kary traktowano jedynie jako środki stymulujące do efektywniejszej pracy. Podkreślano wagę wychowania estetycznego, fizycznego i higieny.

Czasopismo można potraktować jako nowoczesny, jak na ówczesne czasy, poradnik dla wychowawczyń przedszkoli, zapoznający je z metodami pracy dydaktyczno-wychowawczej, opartymi o nowych odkryciach pedagogiki. Szczególnie istotne wydaje się przełożenie treści teoretycznych na praktykę pedagogiczną.

Wiele haseł propagowanych przez pismo jest aktualnych do dziś. Niektóre informacje i materiały metodyczne zawarte w piśmie mogą być wykorzystywane również przez współczesnych nauczycieli, tym bardziej że obecnie na nowo odkrywana jest np. pedagogika M. Montessori, plan daltoński, ośrodki zainteresowań itp. Ponadczasowe zresztą jest hasło, głoszone za F. Froeblem przez redaktorkę pisma Marię Weryho-Radziwiłłowiczową: „Żyjmy dla dzieci!” oraz stwierdzenie, o którym zawsze warto pamiętać: „przedszkole powinno dać dziecku ciepło i serdeczność, żeby lata tam spędzone pozostawiły jasne i dobre wspomnienia i budziły w duszy dziecka podświadomą wiarę i zaufanie do ludzi" (Od redakcji... 1932: 1). Dodatkowo troska o wszechstronny i harmonijny rozwój dziecka z zachowaniem jego indywidualności nie traci nigdy na aktualności.

\section{Bibliografia}

Audemars M., Lafendel L. (1938) Dom Dzieci przy Instytucie J.J. Rousseau, „Wychowanie Przedszkolne", nr 1, s. 6-16.

Audemars M., Lafendel L. (1938) Dom Dzieci przy Instytucie J.J. Rousseau, „Wychowanie Przedszkolne", nr 2, s. 39-44.

B.G. (1926) Przedszkola austriackie (Wiedeń), „Wychowanie Przedszkolne”, nr 10, s. 8-9.

Bańkowska C. (1927a) Jak budzić w dzieciach samodzielność w pracy i zabawie, „Wychowanie Przedszkolne", nr 10, s. 3.

Bańkowska C. (1927b) Twórcza praca wychowawczyni, „Wychowanie Przedszkolne”, nr 3, s. 4. 
Biciulescu M. (1933) Pomoce wychowawcze MAR BIC, „Wychowanie Przedszkolne”, nr 1, s. 31.

Bobieńska Z. (1936) Praktyczne wskazówki do nauki rysunku, „Wychowanie Przedszkolne", nr 1, s. 1-5.

Bobkowska W. (1932) August Wilhelm Fryderyk Froebel, w sto pięćdziesiątq rocznice urodzin, „Wychowanie Przedszkolne”, nr 3, s. 64-69.

Bogdanowicz J. (1939) O błonicy i płonicy, „Wychowanie Przedszkolne”, nr 1, s. 8-10.

Bogdanowiczowa Z. (1928) Znaczenie metody Montessori, „Wychowanie Przedszkolne", nr 6, s. 122-124.

Bogdanowiczowa Z. (1936) Organizacja wychowania przedszkolnego w Stanach Zjednoczonych, „Wychowanie Przedszkolne”, nr 4, s. 134-135.

Chmaj L. (1962) Prądy i kierunki w pedagogice XX wieku, Warszawa, Wydawnictwo Lekarskie PZWL.

Chrościńska I. (1932) Zajęcia praktyczne dla dzieci, „Wychowanie Przedszkolne”, nr 5, s. $152-155$.

Dewey J. (1967) Wybór pism pedagogicznych, J. Pieter (wybór, wstęp), Wrocław, Warszawa, Kraków, Zakład Narodowy im. Ossolińskich.

Drynda D. (2000) Geneza Nowego wychowania w Polsce w: Pedagogika Nowego Wychowania w Polsce u schyłku XIX i w pierwszej połowie XX wieku, A. Meissner, Cz. Majorek (red.), Rzeszów, Wydawnictwo Wyższej Szkoły Pedagogicznej, s. 27-39.

Erdmanówna M. (1937) Zabawki na choinkę, „Wychowanie Przedszkolne”, nr 6, s. 188.

Gromanówna Cz. (1935) Z zajęć praktycznych, „Wychowanie Przedszkolne”, nr 6, s. 184-185.

Grunwald K. (1925) Wychowanie wg Marii Montessori, „Wychowanie Przedszkolne”, nr 6-7, s. 14-19.

H.G. (1932) Obchód 11 listopada, „Wychowanie Przedszkolne”, nr 6, s. 173.

Hoffmanowa M. (1937) Przeziębienie a odporność i zapobieganie, „Wychowanie Przedszkolne", nr 6, s. 171.

Jakimiakowa A. (1925) Przedszkola Paryskie, „Wychowanie Przedszkolne”, nr 8-9, s. 1-11. 
Jamrożek W. (2001) Problematyka opieki nad dzieckiem na kongresach i zjazdach pedagogicznych w Polsce do 1939 roku w: Kongresy i zjazdy pedagogiczne w Polsce w XX wieku, A. Kicowska (red.), Toruń, s. 121-137.

Kabzińska Ł. (2001) Udział polskich pedagogów w Międzynarodowych Kongresach Ligii Nowego Wychowania okresu międzywojennego w: Kongresy i zjazdy pedagogiczne w Polsce w XX wieku, A. Kicowska (red.), Toruń, s. 188-208.

Kabzińska Ł., Kabziński K. (2010) Czasopiśmiennictwo pedagogiczne okresu II Rzeczypospolitej jako źródło refleksji teoretycznej w zakresie dydaktyki w: Czasopiśmiennictwo okresu Drugiej Rzeczypospolitej jako źródło do historii edukacji, I. Michalska, G. Michalski (red.), Łódź, Wydawnictwo UŁ, s. 215-227.

Klecamówna Z. (1939) Zabawki z rafii, „Wychowanie Przedszkolne”, nr 1, s. 27-29.

Kosmowska I. W. (1927) Opieka nad dzieckiem w Rumunii, „Wychowanie Przedszkolne", nr 2, s. 3-5.

Kossuthówna B. (1937) $W$ dniu 11 listopada, „Wychowanie Przedszkolne”, nr 6, s. 165.

Kotarbińska W. (1932) Obrazek sceniczny na Boże Narodzenie, „Wychowanie Przedszkolne", nr 6, s. 186-187.

Lingard M. (1933) Ćwiczenia spostrzegania, „Wychowanie Przedszkolne”, nr 5, s. 157.

Łuniewska F. (1930) Zaziębienie, „Wychowanie Przedszkolne”, nr 11, s. 213-215.

Łuniewska F. (1932) O katarze, „Wychowanie Przedszkolne”, nr 1, s. 6-8.

Łuniewska F. (1936) O odmrożeniach, „Wychowanie Przedszkolne”, nr 1, s. 11-12.

M.F. (1927) Wychowanie przedszkolne w Szwajcarii, „Wychowanie Przedszkolne”, nr 12, s. 7.

Międzynarodowy Kongres Nowego Wychowania w Nicei (1932), „Wychowanie Przedszkolne", nr 6, s. 170-173.

Moliere S. (1982) Maria Weryho-Radziwiłłowiczowa - Życie i praca, „Wychowanie w Przedszkolu", nr 9, s. 458.

Moreau M. (1926) Przedszkola w Belgii, „Wychowanie Przedszkolne”, nr 1, s. 11-12.

Nekrolog O. Decrolego (1932) „Wychowanie Przedszkolne”, nr 6, s. 161.

NN (1927) Na biegunach, „Wychowanie Przedszkolne”, nr 2, s. 23-24.

NN (1930) Ćwiczenia w logicznym myśleniu, „Wychowanie Przedszkolne”, nr 11, s. 228. 
NN (1931) Ćwiczenia gimnastyczne dla dzieci w wieku przedszkolnym, „Wychowanie Przedszkolne", nr 5, s. 171.

NN (1935) Wiersze patriotyczne, „Wychowanie Przedszkolne”, nr 6, s. 177.

Od redakcji (1932), „Wychowanie Przedszkolne”, nr 1, s. 1.

Od redakcji (1936), „Wychowanie Przedszkolne”, nr 2, s. 35-40.

Piotrowska W. (1931) Psychologia indywidualna Adlera jako podstawa naukowa wychowania przedszkolnego, „Wychowanie Przedszkolne”, nr 1, s. 4-6.

Podgórska E. (1931) Ćwiczenia gimnastyczne dla dzieci w wieku przedszkolnym, „Wychowanie Przedszkolne", nr 5, s. 157.

Podgórska E. (1935) Gry i zabawy ruchowe, „Wychowanie Przedszkolne”, nr 6, s. $174-175$.

Podgórska E. (1936a) Ćwiczenia ruchowe „Wychowanie Przedszkolne”, nr 1, s. 9-11.

Podgórska E. (1936b) Skoki - ćwiczenia ruchowe, „Wychowanie Przedszkolne”, nr 3, s. 83.

Podolecka Z. (1928) Z dziedziny wychowania przedszkolnego w Ameryce, „Wychowanie Przedszkolne", nr 10, s. 199-200.

Pyciarzówna W. (1937) Ozdoby z kartonu, „Wychowanie Przedszkolne”, nr 1, s. 25-26.

Raczek M. (2001) Maria Weryho-Radziwiłłowiczowa jako organizatorka wychowania przedszkolnego na ziemiach polskich przełomu XIX i XX wieku w: Rola i miejsce kobiet w edukacji i kulturze polskiej, T. II, W. Jamrożek, D. Żołądź-Strzelczyk (red.), Poznań, Wydawnictwo Uniwersytetu Adama Mickiewicza, s. 81-87.

R. J. (1930) Ćwiczenia zmysłów, „Wychowanie Przedszkolne”, nr 2, s. 253-254.

Schreiber I. (1935) Przedszkola wiedeńskie, „Wychowanie Przedszkolne”, nr 2, s. 34-39.

Sikorska E. (1937) Dlaczego dzień 11 listopada jest świętem narodowym?, „Wychowanie Przedszkolne", nr 6, s. 172-174.

Sobczak J. (1998) „Nowe wychowanie” w polskiej pedagogice okresu Drugiej Rzeczpospolitej (1918-1939), Bydgoszcz, Wydawnictwo Uczelniane Wyższej Szkoły Pedagogicznej. 
Sosnowska J. (2016) Wydawcy polskich czasopism pedagogicznych adresowanych do wychowawczyń przedszkoli i ich rola w popularyzowaniu idei wychowania przedszkolnego w II Rzeczypospolitej w: Oświatowe i edukacyjne aspekty działalności wydawniczej $w$ XX i pierwszych latach XXI wieku, I. Michalska i G. Michalski (red.), Wydawnictwo Uniwersytetu Łódzkiego, s. 1-28.

Sośnicki K. (1967) Rozwój pedagogiki zachodniej na przełomie XIX i XX wieku, Warszawa, Państwowe Zakłady Wydawnictw Szkolnych.

Sterling W. (1930) Jak poznać nieprawidłowy rozwój umysłowy małych dzieci, „Wychowanie Przedszkolne", nr 9, s. 5.

Szuman S. (1931) Higiena psychiczna pierwszego dzieciństwa, „Wychowanie Przedszkolne", nr 5, s. 129-134.

Szuman S. (1932) O życiu uczuciowym małego dziecka i o wychowaniu ucznia, „Wychowanie Przedszkolne", nr 5, s. 130-135.

Uziembło M. (1938) Współpraca przedszkola z domem dziecka, „Wychowanie Przedszkolne", nr 6, s. 167-169.

Weryho M. (1925) Słowo wstępne, „Wychowanie Przedszkolne”, nr 1, s. 1.

W.K. (1935) Imieniny Pana Marszałka, „Wychowanie Przedszkolne”, nr 2, s. 55-56.

Wierzbińska J. (1938) Współpraca rodziców dzieci z wychowawczyniq $w$ dziedzinie umuzykalnienia, „Wychowanie Przedszkolne”, nr 1, s. 3-4.

Witkowski M. (1938) Jeszcze w sprawie współpracy wychowawczej przedszkola i domu, „Wychowanie Przedszkolne”, nr 1, s. 1-2.

Wuttkowa J. (1928) Przedszkola wiedeńskie, „Wychowanie Przedszkolne”, nr 6, s. $126-128$.

Z. B. (1933) Ćwiczenia rachunkowe z liczbq 5, „Wychowanie Przedszkolne”, nr 5, s. $155-156$.

Zarzqdzenie Ministra Wyzwań Religijnych i Oświecenia Publicznego z dn. 20 II 1936 r. Nr II -P527/36 w sprawie kwalifikacji zawodowych wychowawczyń przedszkoli (1936) „Wychowanie Przedszkolne”, nr 2, s. 1-3.

Zgrychowa I. (1939) Teatr kukiełkowy, „Wychowanie Przedszkolne”, nr 5, s. 152-156.

Żukiewiczowa Z. (1927) IV Wszechświatowy Kongres Nowego Wychowania w Locarno, „Wychowanie Przedszkolne”, nr 12, s. 14. 